Revista Brasil. Bot., V.30, n.4, p.695-702, out.-dez. 2007

\title{
Leaf anatomy of two Anemia Sw. species (Schizaeaceae-Pteridophyte) from a rocky outcrop in Niterói, Rio de Janeiro, Brazil
}

\author{
MARIA LUIZA R. C. RIBEIRO', MARCELO GUERRA SANTOS ${ }^{2}$ and \\ MOEMY GOMES MORAES ${ }^{1,3}$
}

(received: September 15, 2004; accepted: December 15, 2005)

\begin{abstract}
Leaf anatomy of two Anemia Sw. species (Schizaeaceae-Pteridophyte) from a rocky outcrop in Niterói, Rio de Janeiro, Brazil). The ferns Anemia tomentosa (Sav.) Sw. var. anthriscifolia (Schrad.) Mickel and Anemia villosa Humb. \& Bonpl. ex Willd. are widely associated with vegetation islands on rocky outcrops in Rio de Janeiro. Both species are desiccation tolerant. The leaf anatomy of these species was examined aiming to identify morphological characteristics that would allow the establishment of these species in water-scarce environments. The plants were harvested on "Pedra de Itacoatiara" and prepared according to the usual procedures. The petiole has a uniseriate epidermis with lignified cell walls, conical stegmata, and uniseriate multicelular and glandular trichomes. In A. villosa, the stomata protrude in a respiratory line. Under the epidermis the cells have thick, lignified walls. The parenchyma has phenolic compounds and starch grains. The petiole vascular bundles are surrounded by endodermis with Casparian strips and the xylem is V-shaped (A. villosa) or arc-shaped (A. tomentosa var. anthriscifolia). The leaf blades have a uniseriate epidermis with sinuous anticlinal and convex periclinal walls, conical stegmata and chloroplasts on both surfaces. The leaf margins of A. villosa have lignified cells. The guard cells of the stomata on the abaxial surface are on the same level or are raised above ordinary epidermal cells. Multicelular uniseriate trichomes and glandular hairs were observed. The dorsiventral mesophyll has loosely packed chlorenchyma with arm-shaped and $\mathrm{H}$-shaped cells. The vascular bundles are surrounded by endodermis with Casparian strips and with parenchymatic extensions towards the epidermis. Anatomical results were analyzed considering the interaction of these plants with abiotic factors.
\end{abstract}

Key words - ecological anatomy, monilophyte, "Pedra de Itacoatiara"

RESUMO - (Anatomia foliar de duas espécies de Anemia Sw. (Schizaeaceae-Pteridófita) de um afloramento rochoso em Niterói, Estado do Rio de Janeiro, Brasil). As pteridófitas Anemia tomentosa (Sav.) Sw. var. anthriscifolia (Schrad.) Mickel e Anemia villosa Humb. \& Bonpl. ex Willd. estão comumente associadas às "ilhas de vegetação" nos afloramentos rochosos do Rio de Janeiro, sendo ambas tolerantes a dessecação. Este trabalho objetivou analisar a anatomia foliar e identificar estratégias morfológicas que possibilitem o estabelecimento destas espécies num ambiente com restrição hídrica. As pteridófitas foram coletadas na Pedra de Itacoatiara e submetidas às técnicas de estudos anatômicos. Os pecíolos das espécies apresentam epiderme unisseriada com paredes lignificadas, estegmatas cônicos, tricomas tectores unisseriados e glandulares. Em A. villosa foram observados estômatos em protrusão formando linha respiratória. Abaixo da epiderme ocorrem camadas de células com paredes espessas e lignificadas. O parênquima possui compostos fenólicos e grãos de amido. Os feixes vasculares dos pecíolos estão envolvidos por endoderme com estrias de Caspary e o xilema tem forma de "V" (A. villosa) ou forma de arco (A. tomentosa var. anthriscifolia). A lâmina foliar apresenta epiderme uniestratificada com paredes anticlinais sinuosas e periclinais convexas, com estegmatas cônicos e cloroplastos nas faces adaxial e abaxial. As células epidérmicas do bordo foliar são lignificadas em A. villosa. Estômatos na face abaxial com células guarda no mesmo nível ou acima das demais células epidérmicas. Foram observados tricomas tectores multicelulares unisseriados e tricomas glandulares. O mesofilo é dorsiventral, com clorênquima frouxo composto por células braciformes e em forma de " $\mathrm{H}$ ". Os feixes vasculares são envolvidos por endoderme com estrias de Caspary e possuem extensões de parênquima em direção à epiderme. Os resultados anatômicos foram analisados considerando a interação dessas plantas com fatores abióticos.

Palavras-chave - anatomia ecológica, monilophyta, Pedra de Itacoatiara

\section{Introduction}

Rocky outcrops are fragile ecosystems with a unique habitat, several endemic species (Meirelles et al. 1999),

1. Universidade Federal Fluminense, Departamento de Biologia Geral, Caixa Postal 100436, 24001-970 Niterói, RJ, Brazil

2. Universidade do Estado do Rio de Janeiro, Faculdade de Formação de Professores

3._Corresponding author: moemy@vm.uff.br and vegetation that is distinctly different from that of surrounding areas (Meirelles 1990, Porembski 2002). These are called "inselbergs" (Porembski 2002) and their plant communities have received little attention from scientists and conservationists (Meirelles et al. 1999).

Inselbergs are considered to be diversity centers of desiccation tolerant species (Porembski \& Barthlott 2000). There are about 300 species of vascular plants that have some level of desiccation tolerance (Porembski \& 
Barthlott 2000). Nine fern families belong to the group with this attribute, especially Selaginellaceae, Pteridaceae and Aspleniaceae (Proctor \& Pence 2002).

Anemia tomentosa (Sav.) Sw. var. anthriscifolia (Schrad.) Mickel and Anemia villosa Humb. \& Bonpl. ex Willd. (Schizaeaceae) are fern species commonly associated with vegetation islands on rocky outcrops in Rio de Janeiro State (Santos \& Sylvestre 2006). Both species are considered to be desiccation tolerant (Gaff 1987, Meirelles 1990).

Biochemical, physiological and morphological mechanisms are found in plants that undergo water shortage (Bohnert et al. 1995, Larcher 2000). Several structural characteristics may contribute to decrease in the rate of water loss, such as reduction of leaf surface, increased thickness of epidermal cell walls, increased thickness of cuticle, high trichome density and stomata located on the abaxial surface (Fahn 1990, Dickinson 2000). In addition to these features, others such as the presence of water storage tissues, high sclerenchyma density and mucilage storage result in improved mechanical conditions and/or reduced tissue damage (Dickinson 2000).

Here we examine the leaf anatomy of A. tomentosa var. anthriscifolia and $A$. villosa from a rocky outcrop in the state of Rio de Janeiro (Niterói) in order to identify morphological characteristics that would allow the establishment of these species in a water-scarce environment.

\section{Material and methods}

Specimens of Anemia tomentosa (Sav.) Sw. var. anthriscifolia (Schrad.) Mickel and Anemia villosa Humb. \& Bonpl. ex Willd. were harvested on "Pedra de Itacoatiara", a gneiss-granitic rocky outcrop located in Niterói, Rio de Janeiro

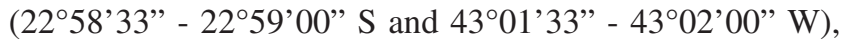
part of the "Parque Estadual da Serra da Tiririca". Vouchers were deposited at the "Faculdade de Formação de Professores" of the "Universidade do Estado do Rio de Janeiro" herbarium (RFFP).

Fully expanded leaves were harvested and fixed in FAA $70 \%$ (Johansen 1940). Cross and longitudinal sections were made of the proximal and distal regions of the petiole, the median region of the pinnae and leaf margins using a stainless steel blade. Sections were cleared using commercial sodium hypochloride (50\%), neutralized and stained with safranine and Astra blue (Bukatsch 1972). Sections were subsequently mounted in glycerin $(50 \%)$. Histochemical tests were made on fresh leaves treated with the following reagents: Sudan III to detect lipid compounds (Jensen 1962); Lugol for starch grains (Langeron 1949); iodated Zinc chloride for cellulose (Jensen 1962). Detection of phenolic compounds was done on leaves fixed in ferrous sulfate (Johansen 1940).
Identification of vascular bundle types followed Ogura (1972), and stomata, Mickel \& Lestern (1967). Results were registered on photomicrographs. The authors of the scientific names were abbreviated according to Pichi-Sermolli (1996) recommendations for pteridophytes.

\section{Results}

The anatomical features of Anemia tomentosa (Sav.) Sw. var. anthriscifolia (Schrad.) Mickel and Anemia villosa Humb. \& Bonpl. ex Willd. leaves are summarized in table 1 . The petioles of both species have a uniseriate epidermis, with thick, lignified cell walls, and conical stegmata (figure 1, table 1). Multicellular uniseriate trichomes and glandular hairs are present in both species. Stomata with protruding guard cells suspended by lignified epidermal cells were observed in A. villosa, forming a respiratory line (figures 2, 5).

Cells below the epidermis have thick, lignified walls, arranged in two to six layers (figures 3,4). The outermost cells have thicker walls (figure 1) when compared to the innermost cells, which may also contain phenolic compounds. Parenchyma cells of both species are filled with starch grains, mainly on the distal petiole (figures 5,7 ), and contain phenolic compounds.

The vascular bundle is arched in A. villosa, which has three in the proximal and one in the distal petiole (figure 3, table 1). A. tomentosa var. anthriscifolia has one vascular bundle along the whole petiole (figure 4, table 1). In both species, the vascular bundle is surrounded by endodermis with Casparian strips (figure 6). The xylem is V-shaped in A. villosa and arc-shaped in A. tomentosa var. anthriscifolia (table 1); xylem margins are curved in both species. The vascular bundle is concentric, with phloem surrounding xylem, and is sometimes discontinuous, giving rise to an inner and outer phloem (figure 6). The parenchyma associated with vascular tissues, including the pericycle, has starch grains and phenolic compounds.

The leaf blades of both species have a uniseriate epidermis, whose cells have mainly sinuous anticlinal walls (figures 8-10) and convex outer periclinal walls, usually with conical stegmata (figures 11, 12, table 1). Chloroplasts are present in the adaxial and abaxial epidermis. Near the veins, epidermal cells are elongate with thicker walls, mainly on the adaxial surface. The cells below this layer have similar characteristics (figures 11, 12).

Stomata are found only on the abaxial surface. Guard cells are located at the same level or above the epidermal cells (figure 11). Most stomata are applied in both species (figure 8), but they differ as regards the additional type found. A. villosa has stomata suspended by a projection 



3
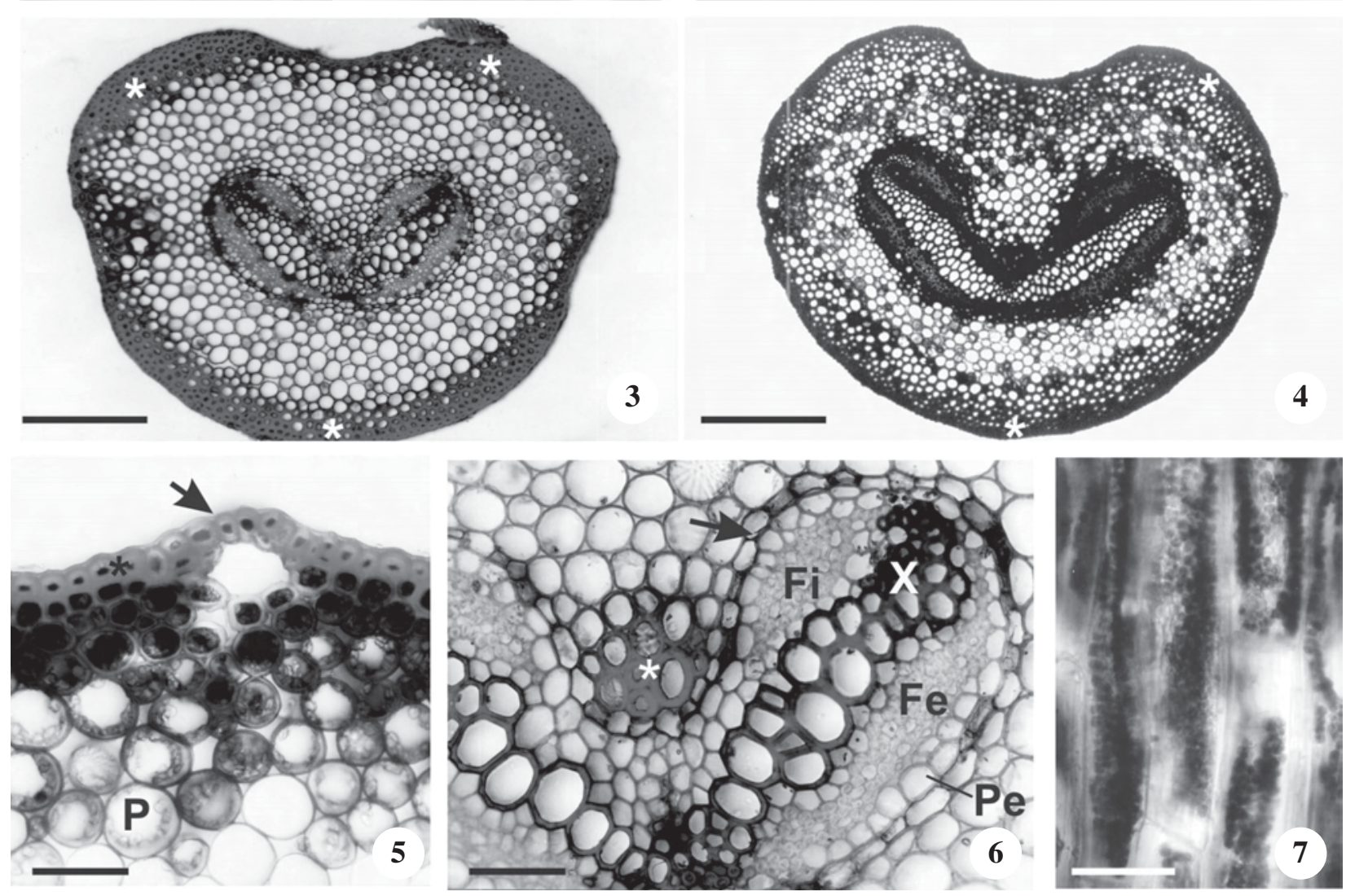

Figures 1-7. Petiole anatomy of Anemia species: 1 . Cross section of A. tomentosa var. anthriscifolia petiole showing epidermis with conical stegmata (arrow) and layers of lignified cells below the epidermis. 2. A. villosa stomata in protrusion supported by lignified cells (arrow). 3. A. villosa distal petiole; layers of cells with lignified walls (*); arched vascular bundle with V-shaped xylem. 4. A. tomentosa var. anthriscifolia distal petiole; layers of cells with lignified walls (*); arched vascular bundle with arc-shaped xylem. 5. A. villosa with lignified epidermis (*); cortex parenchyma storing starch grains; elevated epidermal cells (arrow). 6. Detail of A. villosa vascular bundle showing lignified cells in the inner arc (*); endodermis with Casparian strips (arrow). 7. A. tomentosa var. anthriscifolia petiole in longitudinal section showing starch grains stained with lugol inside parenchyma cells. $(\mathrm{E}=$ epidermis; $\mathrm{Fe}=$ outer phloem; $\mathrm{Fi}=$ inner phloem; $\mathrm{P}=$ parenchyma; $\mathrm{Pe}=$ pericycle; $\mathrm{X}=\mathrm{xylem}$ ). Bars $=20 \mu \mathrm{m}(1,2,7), 50 \mu \mathrm{m}(5,6), 300 \mu \mathrm{m}(3,4)$.

of the anticlinal wall (figure 8) while A. tomentosa var. anthriscifolia has floating stomata. Trichomes are glandular and multicellular uniseriate (figure 9, 10).

The dorsiventral mesophyll has loosely packed chlorenchyma composed of arm-shaped cells (figures $11,12)$. On the adaxial surface, these cells are elongate and $\mathrm{H}$-shaped (figures 13, 14). The collateral vascular bundles are surrounded by endodermis with Casparian strips (figure 15). Parenchyma forms bundle-sheath extensions. Leaf margins have lignified cells in A. villosa (figure 16) but not in A. tomentosa var. anthriscifolia (figure 17). 
Table 1. Leaf characteristics of Anemia tomentosa (Sav.) Sw. var. anthriscifolia (Schrad.) Mickel and Anemia villosa Humb. \& Bonpl. ex Willd. from "Pedra de Itacoatiara", Niterói, Rio de Janeiro State, Brazil.

\begin{tabular}{|c|c|c|}
\hline Characteristics & A. tomentosa & A. villosa \\
\hline \multicolumn{3}{|l|}{ Petiole } \\
\hline Stomata in protrusion & - & + \\
\hline Glandular hairs & + & + \\
\hline $\begin{array}{l}\text { Multicelular uniseriate } \\
\text { trichomes }\end{array}$ & + & + \\
\hline $\begin{array}{l}\text { Epidermal cells with } \\
\text { lignified walls }\end{array}$ & + & + \\
\hline Conical stegmata & + & + \\
\hline $\begin{array}{l}\text { Cortex parenchyma } \\
\text { containing starch grains }\end{array}$ & + & + \\
\hline $\begin{array}{l}\text { Vascular bundle with } \\
\text { V-shaped xylem }\end{array}$ & - & + \\
\hline $\begin{array}{l}\text { Vascular bundle with } \\
\text { arc-shaped xylem }\end{array}$ & + & - \\
\hline $\begin{array}{l}\text { Vascular bundle number } \\
\text { at proximal region }\end{array}$ & 1 & 3 \\
\hline $\begin{array}{l}\text { Vascular bundle number } \\
\text { at distal region }\end{array}$ & 1 & 1 \\
\hline \multicolumn{3}{|l|}{ Leaf blade } \\
\hline Hypostomatic leaf & + & + \\
\hline Floating stomata & + & - \\
\hline $\begin{array}{l}\text { Stomata suspended by a } \\
\text { projection of anticlinal wall }\end{array}$ & - & + \\
\hline Applied stomata & + & + \\
\hline Glandular hairs & + & + \\
\hline $\begin{array}{l}\text { Multicellular uniseriate } \\
\text { trichomes }\end{array}$ & + & + \\
\hline $\begin{array}{l}\text { Epidermal cells with sinuous } \\
\text { walls }\end{array}$ & + & + \\
\hline Conical stegmata & + & + \\
\hline $\begin{array}{l}\text { Mesophyll with arm-shaped } \\
\text { cells of chlorenchyma }\end{array}$ & + & + \\
\hline Collateral vascular bundle & + & + \\
\hline $\begin{array}{l}\text { Lignified cells on leaf } \\
\text { margins }\end{array}$ & - & + \\
\hline
\end{tabular}

\section{Discussion}

Studies on the anatomy of plants that live in dry, nutrient-poor habitats have shown that these species have xeromorphic characteristics which may prevent water loss (Castro \& Menezes 1995). Pteridophytes are outstanding in their capacity to occupy marginal environments under extreme conditions (Page 2002). This author also emphasizes that most Schizaeaceae species grow vigorously in nutrient-poor environments. However the anatomy of pteridophytes living under these conditions has been underexploited. Several epidermal cell characteristics have been linked to the avoidance of excessive water loss and high light levels; these include cuticle and external wall thickness, relative stomata position and trichome density (Fahn 1990, Dickinson 2000).

In this study we observed anatomical peculiarities of the petiole and leaf blade epidermis of Anemia tomentosa (Sav.) Sw. var. anthriscifolia (Schrad.) Mickel and Anemia villosa Humb. \& Bonpl. ex Willd. The presence of stegmata on the periclinal walls of epidermal cells deserves attention. According to Ogura (1972), this is a common characteristic of the genus. These structures are composed of silica, which can form crystals inside the cell or become incrusted on the cell wall, as was observed for the species studied here. The presence of stegmata seems to be restricted to certain plant groups like the Orchidaceae, Musaceae, Poaceae and Pteridophytes. Furthermore, these structures have specific shapes and locations, which lead Prychid et al. (2004) to stress the potential use of stegmata for the systematics of the groups in which they occur (see Møller \& Rasmussen 1984).

With respect to the possible functions carried out by these structures, Prychid et al. (2004) mention that silica may help to maintain rigidity in organs with stegmata, and it also may be related to reducing herbivory, grazing and infection by microorganisms. When present in the blade epidermis, they may reduce transpiration, thus improving water-use efficiency. In the species studied here, stegmata were observed in the petiole epidermis, close to lignified cells, and also above the vascular bundles in the leaf blade. They may therefore act in frond support. Some authors found a tendency for the presence of stegmata in the epidermis to be associated with xeromorphic characteristics, as exemplified by the orchid Cattleya araguaiensis Pabst (Zanenga-Godoy \& Costa 2003) and other epiphytes. They are absent in mesomorphic orchids (Møller \& Rasmussen 1984).

Another prominent characteristic is the distinct, diversified stomata types in pteridophytes (Sen \& De 1992). In some species, the guard cells of the stomata are entirely surrounded by one epidermal cell. This condition, described as "floating stomata" or adetostomy (Mickel 1962), is common in Anemia and can also be found in Pyrrosia Mirb. and in some Drymoglossum C. Presl, Lemmaphyllum C. Presl and Campyloneurum C. 

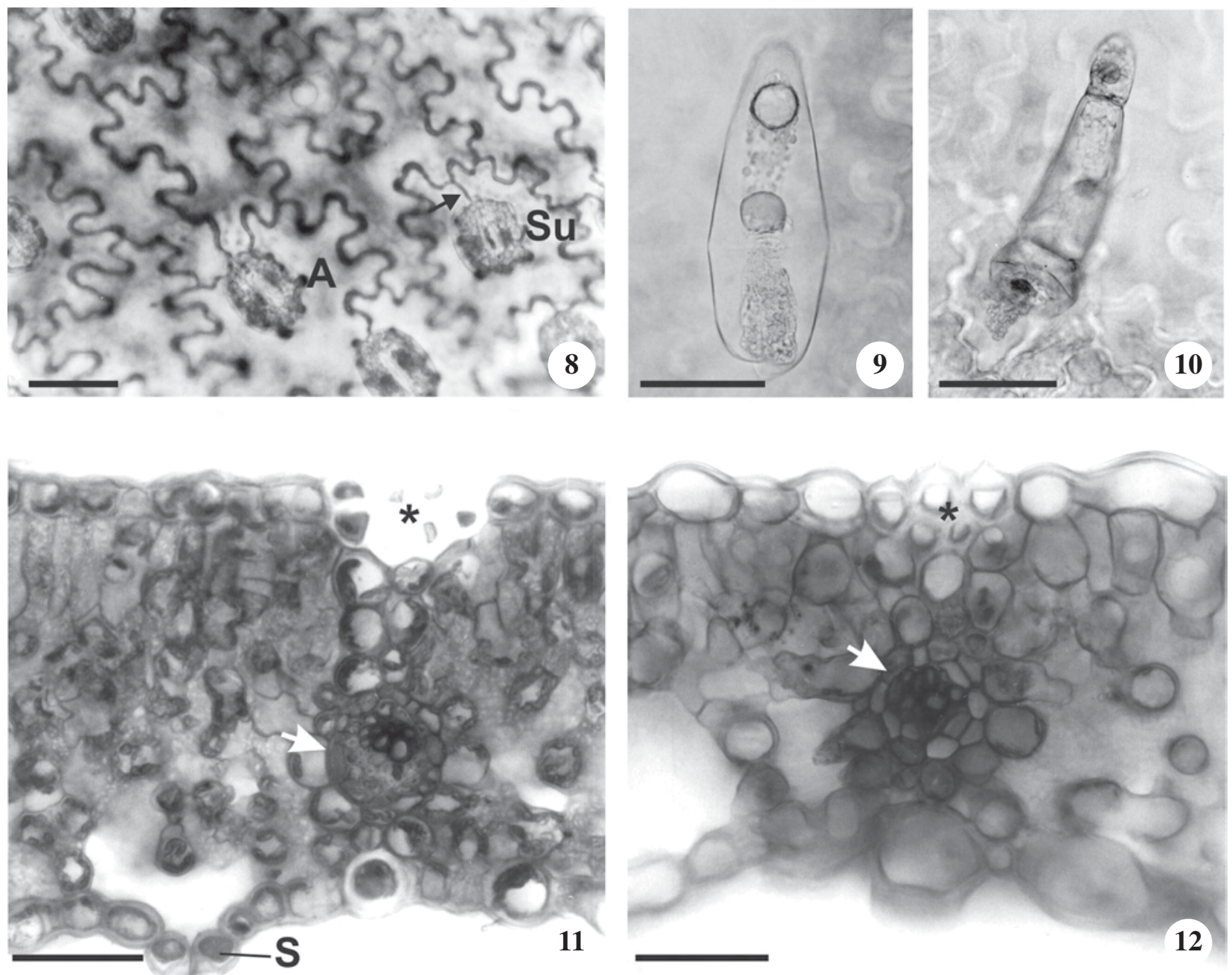

Figures 8-12. Leaf blade anatomy of Anemia species: 8. Abaxial surface of A. villosa epidermis, with applied stomata (A) and suspended $(\mathrm{Su})$ by a projection of the anticlinal wall (arrow). 9. Apical cell of glandular hair on A. villosa epidermis. 10. Glandular hair with 3 cells on A. villosa epidermis. 11. Cross section of A. tomentosa var. anthriscifolia leaf blade showing stegmata $(*)$, parenchyma surrounding the vascular bundle (arrow) and stomata in protrusion (S). 12. Cross section of $A$. villosa leaf blade showing stegmata $(*)$ and parenchyma surrounding the vascular bundle $($ arrow $)$. Bars $=20 \mu \mathrm{m}$ $(9,10), 50 \mu \mathrm{m}(8,11,12)$.

Presl species (Mickel \& Lersten 1967). Applied stomata are the main type found here. The guard cells have lateral contact with more than one epidermal cell; however, the species differ in that A. tomentosa var. anthriscifolia has floating stomata, while A. villosa has stomata suspended by a projection of the anticlinal wall. Guard cells in protrusion are present in these species, a feature found mostly in species where water is abundant. Ogura (1972) mentions this condition in Anemia Sw. and Schizaea Sm.

In a study focusing on the ontogeny of fern stomata, Sen \& De (1992) used different names for the types describe above. Applied stomata are polocytic, the most widely distributed type in ferns. Suspended stomata are desmocytic and floating stomata are pericytic. These authors demonstrated ontogenetic relationships between these types of stomata and proposed that polocytic is the basal form of other types, including desmocytic and polocytic. The same study reports the presence of four other types of stomata in A. villosa, but they were not observed in this study. No functional or ecological relationship of the referred stomata was proposed by Mickel \& Lestern (1967) and Sen \& De (1992).

Besides the special types found in the leaf blade, stomata in protrusion were found along the petiole in $A$. villosa. According to Ogura (1972) this arrangement constitutes a respiratory line, which probably provides aeration since the hypodermis layer is interrupted under this line. In this respect, Haberlandt (1928) mentioned that stomata in protrusion are common in species densely 

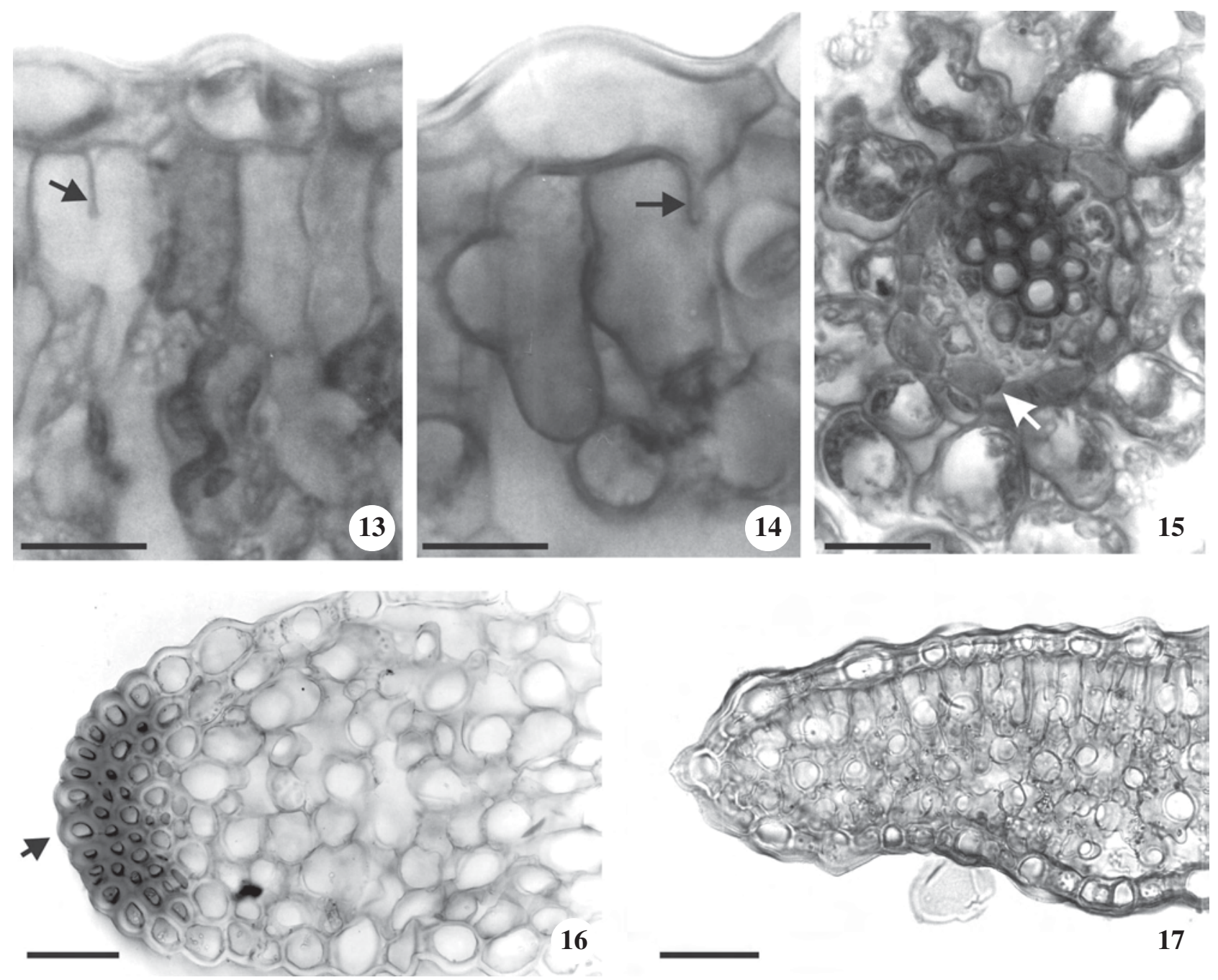

Figures 13-17. Leaf blade anatomy of Anemia species: 13. A. tomentosa var. anthriscifolia: detail of $\mathrm{H}$-shaped parenchyma (arrow). 14. A. villosa: detail of $\mathrm{H}$-shaped parenchyma (arrow). 15. Collateral bundle in A. tomentosa var. anthriscifolia showing endodermis with Casparian strips (arrow). 16. Cross section of A. villosa leaf margin showing cells with lignified walls (arrow). 17. Cross section of A. tomentosa var. anthriscifolia leaf margin. Bars $=20 \mu \mathrm{m}(13-15), 50 \mu \mathrm{m}(16,17)$.

covered by trichomes. These stomata differ from those described by Haberlandt (1928) and Metcalfe \& Chalk (1979) by having lignified cells distinct from the other epidermal cells. Their elongate shape projects them outwards, while the stomata described by the abovementioned authors have similar epidermal cells projected not due to their shape, but to their distinct disposition along the tissue.

In addition to stomata types, the epidermis of the blade has sinuous anticlinal walls. Haberlandt (1928) proposed that this feature increases contact between adjacent cells, and may help to maintain leaf structure under mechanical stress. "Pedra de Itacoatiara" is located near the sea and is exposed to strong winds. The vegetation is exposed to substrate limitations causing leaf blades to roll up when water is scarce.
Similarly, trichomes are referred to as plant protection features and both species have glandular hairs containing oil. The essential oil of $A$. tomentosa var. anthriscifolia is sesquiterpene isoafricanol (Santos et al. 2003). A. villosa essential oil was also extracted, but the component has yet to be identified (Santos \& Sylvestre 2006). Such substances may act as allelochemicals and may be helpful in chemotaxonomy. Several sesquiterpenes have been correlated with plant protection and monoterpenes (e.g. gossypol) show insecticide activity (Croteau et al. 2000).

As regards the fundamental tissues, attention should be drawn to the arm- and $\mathrm{H}$-shaped mesophyll cells. This type of cell is generally found in plants from wet or aquatic habitats (Fahn 1990), conferring ample intercellular space for gas diffusion. Leaf structure was reported as the most important factor in leaf assimilation 
capacity (Niinemets 1999). Haberlandt (1928) reports that H-shaped cells, such as observed in these Anemia species, permit a higher exposure surface for chloroplasts. Moreover, the connections between cells create an efficient route for substance conduction towards the vascular bundle. During photosynthetic events, such as light capture and distribution, oxygen production, carbon dioxide diffusion and fixation, leaf tissues cooperate and their structure greatly contributes to the entire process (Vogelman et al. 1996). The species studied here have chloroplasts inside the epidermal cells, suggesting a role for this tissue beyond optimization of light absorption during photosynthesis.

Plants growing in habitats with contrasting environmental conditions of water availability may show distinct mesophyll architecture. Leaves of xeromorphic species tend to be more compact. Slaton \& Smith (2002) mention that there is up to $95 \%$ contact surface between cells and little contact with intercellular spaces. The tendency to have relatively large intercellular spaces has already been observed in xeromorphic species with dorsiventral mesophyll and abaxial surface densely covered by trichomes (Burrows 2001). The leaf blades of the species studied here have this configuration, although they lack the dense covering of trichomes.

Starch grains were observed in the petiole parenchyma, indicating a storage function for this leaf part, especially in A. villosa, that has a reduced rhizome. Nevertheless this characteristic may be associated with the prevention of mechanical damages in plasmalema during reduced water availability, as suggested by Vicré et al. (1999) for tissues of desiccation tolerant seeds.

Another factor associated with the protection of these species is the presence of phenolic compounds located mainly in the supporting tissues and close to the parenchyma of the bundles. These compounds are commonly found in ferns (Ogura 1972), as related by Graçano et al. (2001) for Pteridaceae species. According to Croteau et al. (2000) these compounds were important for plant adaptation to the terrestrial environment, as much as structural component, as in several defense processes to biotic and abiotic factors. Waterman \& Mole (1994) emphasize their importance for plant protection in circumstances, such as drought, high light intensity and other soil conditions. However it is unclear how these substances behave and how they function in response to drought. Gershezon (1983) suggested that increased substance levels may be the result of reduction in growth rates and synthesis of lignin precursors.

Another characteristic that deserves attention is the presence of endodermal cells girdled by Casparian strips around the vascular bundles of the petiole and leaf blade, a common feature of ferns (Ogura 1972). In Angiosperms this feature is always found in roots, frequently in underground or submerged stems, and seldom in leaves (Lestern 1997). Its function has been related to solute retention in the stele and sap flow canalization, thus forming closed, defined apoplastic routes (Lestern 1997, Yokoyama \& Karahara 2001). It is also essential for the protection of aerenchyma chambers in submerged plants (Dalla Vechia et al. 1999). In the species studied here, the endodermis may insure greater efficiency in sap flow to the leaf blades. On the other hand, xeromorphic features of the petiole suggest it is a structural adjustment to water shortage.

In spite of the environmental restrictions imposed by the rocky outcrop habitat, Anemia species from "Pedra de Itacoatiara" have leaf blades with mesomorphic characteristics which contrast with the xeromorphic petiole. This raises some questions about survival strategies in these environments such as: Are mesomorphic leaf characteristics conservative or are they adaptations to microclimatic variations? What mechanisms regulate photosynthesis, water balance and plant development?

Acknowledgements - The authors thank Dra. Dorothy Sue Dunn de Araujo (UFRJ) for the English revision and Dr. Alphonse Kelecom for the valuable suggestions.

\section{References}

BOHNERT, H.J., NELSON, D.E. \& JENSEN, R.G. 1995. Adaptations to environmental stresses. Plant Cell 7: 1099-1111.

BUKATCH A. 1972. Bemerkungen zur Doppel färburng Astrablau-Safranin. Mikrokosmos 61:255.

BURROWS, G.E. 2001. Comparative anatomy of the photosynthetic organs of 39 xeromorphic species from subhumid New South Wales, Australia. International Journal of Plant Science 162:411-430.

CASTRO, N.M. \& MENEZES, N.L. 1995. Aspectos da anatomia foliar de algumas espécies de Paepalanthus Kunth, Eriocaulaceae da Serra do Cipó (Minas Gerais). Acta Botanica Brasilica 9:213-229.

CROTEAU, R., KUTCHAN, T.M., LEWIS, N.G. 2000. Natural products (secondary metabolites) In Biochemistry and molecular biology of plants. (B. Buchanan, W. Gruissem \& R. Sones, eds.). American Society of Plant Physiologists, Rockville, p.1250-1318.

DALLA VECHIA, F., CUCCATO, F., LA ROCCA, N., LARCHER, W. \& RACIO, N. 1999. Endodermis-like sheaths in the submerged freshwater macrophyte Ranunculus trichophyllus Chaix. Annals of Botany 83: 93-97. 
DICKINSON, W.C. 2000. Integrative plant anatomy. Academic Press, San Diego.

FAHN, A. 1990. Plant anatomy. Pergamon Press, Oxford.

GAFF, D.F. 1987. Desiccation tolerant plants in South America. Oecologia 74:133-136.

GERSHEZON, J. 1983. Changes in the levels of plant secondary metabolites under water and nutrient stress. Recent Advances in Phytochemistry 18:273-320.

GRAÇANO, D., AZEVEDO A.A. \& PRADO, J. 2001. Anatomia foliar das espécies de Pteridaceae do Parque Estadual do Rio Doce (PERD)-MG. Revista Brasileira de Botânica 24:333-347.

HABERLANDT, G. 1928. Physiological Plant Anatomy. MacMillan Company, London.

JENSEN, W.A. 1962. Botanical histochemistry: Principles and practice. W.H. Freeman, San Francisco.

JOHANSEN, D. 1940. Plant microtechnique. McGraw-Hill, New York.

LANGERON, M. 1949. Précis de microscopie. Masson, Paris. LARCHER, W. 2000. Ecofisiologia Vegetal. RiMa, São Carlos.

LESTERN, N.R. 1997. Occurrence of endodermis with a casparian strip in stem and leaf. The Botanical Review 63:265-270.

MEIRELLES, S.T. 1990. Ecologia da vegetação de afloramentos rochosos do litoral sudeste. Dissertação de mestrado, Universidade Estadual de Campinas, Campinas.

MEIRELLES, S.R., PIVELLO, V.R. \& JOLY, C.A. 1999. The vegetation of granite rock outcrops in Rio de Janeiro, Brazil, and the need for its protection. Environmental Conservation 26:10-20.

METCALFE, C.R. \& CHALK, L. 1979. Anatomy of the dicotyledons. Claredon Press, Oxford.

MICKEL, J.T. 1962. A monographic study of the fern genus Anemia, subgenus Coptophyllum. Iowa State Journal of Science 36:349-482.

MICKEL, J.T., LERSTEN, N.R. 1967. Floating stomates (adetostomy) in ferns: distribution and ontogeny. American Journal of Botany 54:1181-1185.

MØLLER, J.D \& RASMUSSEN, H. 1984. Stegmata in Orchidales: character state distribution and polarity. Botanical Journal of the Linnean Society 80:53-76.

NIINEMETS, Ü. 1999. Components of leaf dry mass per area - thickness and density - alter leaf photosynthetic capacity in reverse directions in woody plants. New Phytologist 144:35-47.

OGURA, Y. 1972. Comparative anatomy of vegetative organs of the pteridophytes. Gebruder Borntraeger, Berlin.

PAGE, C.N. 2002. Ecological strategies in fern evolution: a neopteridological overview. Review of Paleobotany and Palynology 119:1-33.

PICHI-SERMOLLI, R.E.G. 1996. Authors of scientific names in Pteridophyta. Royal Botanic Gardens, Kew.
POREMBSKI, S. 2002. Terrestrial habitat islands as model systems for biodiversity research. In Biodiversidade, conservação e uso sustentável da flora do Brasil (E.L. Araújo, A.N. Moura, E.V.S.B. Sampaio, L.M.S. Gestinari \& J.M.T. Carneiro, eds.). Universidade Federal Rural de Pernambuco, Recife, p.158-161.

POREMBSKI, S. \& BARTHLOT, W. 2000. Granitic and gneissic outcrops (inselbergs) as centers of diversity for desiccationtolerant vascular plants. Plant Ecology 151:19-28.

PROCTOR, M.C.F. \& PENCE, V.C. 2002. Vegetative tissues: Bryophytes, vascular resurrection plants and vegetative propagules. In Desiccation and survival in plants: Drying without dying (M. Black \& W. Pritchard, eds.). Cabi Publishing, Wallingford, p.207-237.

PRYCHID, C.J., RUDALL, P.J. \& GREGORY, M. 2004. Systematics and biology of silica bodies in Monocotyledons. The Botanical Review 69:377-440.

SANTOS, M.G., ROCHA, L.M., CARVALHO, E.S. \& KELECOM, A. 2003. Isoafricanol, um sesquiterpeno incomum encontrado em Anemia tomentosa var. anthriscifolia (pteridófita). In Anais do II Simpósio Brasileiro de Óleos Essenciais (M.O.M. Marques, J.P.F. Teixeira \& S. Scramin, coords.). Instituto Agronômico de Campinas, Campinas, v.74, p.58.

SANTOS, M.G. \& SYLVESTRE, L.S. 2006. Aspectos florísticos e econômicos das pteridófitas de um afloramento rochoso no Estado do Rio de Janeiro, Brasil. Acta Botanica Brasilica 20:115-124.

SEN, U. \& DE, B. 1992. Structure and ontogeny of stomata in ferns. Blumea 37:239-261.

SLATON, M.R. \& SMITH, W.K. 2002. Mesophyll architecture and cell exposure to intercellular air space in alpine, desert, and forest species. International Journal of Plant Sciences 163:937-948.

VICRÉ, M., SHERWIN, H.W., DRIOUICH, A., JAFFER, M.A. \& FARRANT, J.M. 1999. Cell wall characteristics and structure of hydrated and dry leaves of the resurrection plant Craterostigma wilmsii, a microscopical study. Journal of Plant Physiology 155:719-726.

VOGELMAN, T.C., NISHIO, J.N. \& SMITH, W.K. 1996. Leaves and light capture: light propagation and gradients of carbon fixation within leaves. Trends in Plant Science 1:65-70.

WATERMAN, P.G. \& MOLE, S. 1994. Analysis of phenolic plant metabolites. Blackwell Scientific Publications, Oxford.

YOKOYAMA, M. \& KARAHARA, I. 2001. Radial widening of the Casparian strip follows induced radial expansion of endodermal cells. Planta 213:474-477.

ZANENGA-GODOY, R. \& COSTA, C.G. 2003 Anatomia foliar de quatro espécies do gênero Cattleya Lindl. (Orchidaceae) do Planalto Central Brasileiro. Acta Botanica Brasilica 17:101-118. 